\title{
PERANAN PELAYANAN PERPUSTAKAAN DALAM MEMBANTU KEBERHASILAN BELAJAR MAHASISWA TUNANETRA: Studi Kasus di Perpustakaan UIN Sunan Kalijaga Yogyakarta
}

\author{
Aswi Malik Sholikhah, Heni Setiyaningsih \\ Prodi Ilmu Perpustakaan, Fakultas Adab dan Ilmu Budaya UIN-Suka Yogyakarta
}

\begin{abstract}
Penelitian ini bertujuan untuk mengetahui bagaimana peran pelayanan Perpustakaan UIN Sunan Kalijaga Yogyakarta bagi mahasiswa tunanetra terhadap keberhasilan proses belajar. Penelitian ini merupakan penelitian deskriptif kualitatif yang dilakukan secara langsung terhadap objek yang diteliti untuk mendapatkan data-data yang dibutuhkan dan berkaitan dengan rumusan masalah. Metode pengumpulan data yang digunakan dalam penelitian ini menggunakan metode purposive sampling. Sampel dalam penelitian ini adalah mahasiswa tunanetra yang aktif menggunakan pelayanan Perpustakaan UIN Sunan Kalijaga Yogyakarta. Hasil penelitian ini menunjukkan bahwa peran pelayanan Perpustakaan UIN Sunan Kalijaga Yogyakarta bagi mahasiswa tunanetra sudah memberikan kepuasan kepada mereka. Fasilitas yang ada sudah tergolong cukup baik dan dapat membantu pelayanan perpustakaan, sehingga dapat mendukung proses kegiatan belajar diperpustakaan dalam meningkatkan prestasi akademik. Peranan pelayanan perpustakaan dan sikap petugas perpustakaan yang memuaskan kepada pemustaka difabel dapat mempengaruhi kegemaran berkunjung ke perpustakaan.
\end{abstract}

Kata Kunci: mahasiswa tunanetra, pelayanan perpustakaan, sikap petugas perpustakaan

\section{Pendahuluan}

Tujuan pokok perpustakaan adalah memberikan pelayanan kepada pemustaka dengan sebaik-baiknya, terutama pelayanan dalam pemberian informasi. Pelayanan perpustakaan kepada pemustaka tidak memandang faktor ras, umur, jenis kelamin, pendidikan, kondisi fisik dan lain-lain. Hal ini bertujuan agar perpustakaan dalam melayani dapat memberikan kepuasan kepada pemustaka secara menyeluruh.

Menurut Lasa (2005: 49) Perpustakaan sebagai organisasi publik memberikan pelayanan informasi kepada siapa saja yang membutuhkan dengan mengutamakan kepuasan pemustaka. Dari pernyataan di atas jelas bahwa perpustakaan wajib memberikan pelayanan informasi kepada siapa saja termasuk pada pemustaka yang mempunyai keterbatasan fisik, karena setiap pemustaka berhak mendapatkan pelayanan yang baik di perpustakaan. Pelayanan yang baik pada dasarnya berorientasi kepada kepuasan pengunjung. Orang-orang difabel memang memiliki keterbatasan fisik misalnya tunanetra, mereka masih bisa mendapatkan informasi melalui indra lain, untuk mendukung keluasaan akses informasi sebagai sumber belajar.

Universitas Islam Negeri Sunan Kalijaga merupakan salah satu universitas Islam inklusi karena menyediakan Pusat Layanan Difabel (PLD). PLD merupakan pusat belajar dan layanan yang diperuntukkan bagi mahasiswa difabel dalam mengatasi segala bentuk diskriminasi di lingkungan kampus. Perpustakaan ini juga menyediakan berbagai layanan untuk difabel yaitu layanan informasi, layanan multimedia, layanan serial, layanan referensi, layanan sirkulasi, dan layanan difabel corner.

Berdasarkan wawancara penulis dengan mahasiswa tunanetra pada tanggal 7 November 2013 dengan saudara Rahman Agus Priyono semester 3 Jurusan Pendidikan Agama Islam menyatakan bahwa secara keseluruhan pelayanan Perpustakaan UIN Sunan Kalijaga sudah baik. Petugas perpustakaan ramah dan akses untuk masuk ke perpustakaan mudah, fasilitas yang ada sudah bagus, koleksi yang disediakan sudah lengkap. Sedangkan berdasarkan wawancara dengan saudara 
Fikri mahasiswa semester III Pascasarjana UIN Sunan Kalijaga juga menyatakan bahwa pelayanan di Perpustakaan UIN Sunan Kalijaga lumayan bagus, koleksi yang ada lumayan lengkap. Sedangkan dari hasil wawancara dengan Isrowiyanti, S.Ag., SS selaku koordinator layanan informasi Perpustakaan UIN Sunan Kalijaga menyatakan pihak perpustakaan sudah memberikan pelayanan dan fasilitas perpustakaan secara maksimal, dan pihak pustakawan memberikan perhatian yang khusus bagi mahasiswa difabel dalam memberikan pelayanan.

Dari hasil pra-observasi di atas dapat diketahui bahwa pelayanan dan fasilitas Perpustakaan UIN Sunan Kalijaga sudah bagus. Sesuai uraian singkat di atas penulis tertarik untuk melakukan penelitian lebih lanjut mengenai Peranan Pelayanan Perpustakaan dalam membantu Keberhasilan Belajar Mahasiswa Difabel Tunanetra UIN Sunan Kalijaga. Penulis mengambil tempat penelitian di UIN Sunan Kalijaga karena dikenal dengan kampus inklusi dimana terdapat kesetaraan antara orangorang yang normal dengan orang-orang yang mempunyai keterbatasan khusus, baik dari segi pelayanan, fasilitas, dan koleksi yang disediakan.

\section{Rumusan Masalah}

Berdasarkan uraian latar belakang di atas, maka rumusan masalah yang akan dikaji adalah "Bagaimana Peranan Pelayanan Perpustakaan dalam membantu Keberhasilan Belajar Mahasiswa Difabel Tunanetra di UIN Sunan Kalijaga?"

\section{Tujuan Penelitian}

Tujuan dari penelitian ini adalah untuk mengetahui Peranan Pelayanan Perpustakaan dalam membantu Keberhasilan Belajar Mahasiswa Difabel Tunanetra di UIN SunanKalijaga

\section{Manfaat Penelitian}

1. Secara teoritis, penelitian ini diharapkan memberikan khasanah keilmuan, wawasan dan aspek ilmu pengetahuan dan dapat memberi sumbangan terhadap pengembangan ilmu perpustakaan.
2. Secara praksis penelitian ini diharapkan mampu memberikan kontribusi kepada lembaga atau instansi untuk mengembangkan hasil penelitian terkait dengan pelayanan perpustakaan dalam membantu keberhasilan belajar mahasiswa difabel tunanetra di UIN Sunan Kalijaga.

3. Sebagai bahan evaluasi terhadap peranan pelayanan perpustakaan dalam keberhasilan belajar mahasiswa di Perpustakaan UIN Sunan Kalijaga Yogyakarta.

\section{Kajian Pustaka}

Berdasarkan hasil penelusuran yang dilakukan terhadap beberapa penelitian yang sejenis, ditemukan hasil penelitian yang dilakukan sebelumnya. Penelitian yang pertama dilakukan oleh Sumaryanto (2011) di dalam skripsinya yang berjudul "Upaya Pusat Studi Layanan Difabel Dalam Membantu Keberhasilan Belajar Mahasiswa Tunanetra UIN Sunan Kalijaga". Penelitian ini menggunakan deskriptif kualitatif. Pengumpulan data dilakukan dengan menggunakan beberapa metode yaitu wawancara, observasi dan dokumentasi. Hasil penelitian ini menyimpulkan: Pertama, upaya Pusat Layanan Difabel (PLD) dalam membantu keberhasilan belajar mahasiswa tunanetra adalah dengan bimbingan, nasehat, melatih kemandirian, pendampingan individu, orientasi mobilitas, latihan komputer, latihan bahasa Inggris dan workshop. Kedua, kondisi belajar yang terjadi setelah diterapkannya program layanan yaitu: mahasiswa mampu belajar secara mandiri, mampu mengoperasikan komputer, dan mampu menggunakan jaringan internet dalam memenuhi kebutuhan belajarnya. Ketiga, kendala atau penghambat yang dihadapi adalah karena keterbatasan fasilitas yang memadai, gangguan fisik atau kesehatan, serta rendahnya kesadaran mahasiswa dalam berkonsultasi dengan pembimbing.

Penelitian yang kedua dilakukan oleh Toha Sutono (2013) yang berjudul" Persepsi Mahasiswa Difabel terhadap kualitas pelayanan Perpustakaan UIN Sunan Kalijaga Yogyakarta". Penelitian ini menggunakan deskriptif kuantitatif. Pengumpulan data dilakukan dengan metode kuesioner, wawancara, observasi, dan dokumentasi. Hasil penelitian ini menunjukkan 
bahwa persepsi mahasiswa difabel terhadap kualitas pelayanan Perpustakaan UIN Sunan Kalijaga dikategorikan baik dengan hasil total nilai rata-rata 2,97, dengan rincian 2,98 untuk dimensi kehandalan, 3,06 untuk dimensi daya tangkap, 3,21 untuk dimensi jaminan, 2,01 untuk dimensi perhatian, dan 2,62 untuk dimensi bukti fisik. Dari nilai rata-rata tersebut, persepsi mahasiswa difabel terhadap kualitas pelayanan perpustakaan UIN Sunan Kalijaga dikategorikan baik.

Berdasarkan penemuan penelitian di atas, yang pernah dilakukan sebelumnya, terdapat perbedaan dengan penelitian yang dilakukan peneliti saat ini pada fokus penelitian, subjek penelitian, dan waktu penelitian dengan penelitian yang akan penulis lakukan. Penelitian ini lebih menekankan pada peranan pelayanan Perpustakaan dalam keberhasilan belajar mahasiswa difabel tunanetra UIN Sunan Kalijaga.

\section{Metode Penelitian}

\section{Jenis Penelitian}

Penelitian ini merupakan penelitian tentang peran pelayanan Perpustakaan UIN Sunan Kalijaga Yogyakarta bagi mahasiswa difabel, khususnya pada mahasiswa tunanetra.

Dalam penelitian ini penulis menggunakan metode deskriptif kualitatif. Data diperoleh secara rasional dengan menggunakan pola pikir tertentu menurut logika yang dapat menggambarkan keadaan yang sesuai dengan kenyataan.

\section{Tempat Penelitian}

Penelitian dilakukan di Perpustakaan UIN Sunan Kalijaga Yogyakarta.

\section{Waktu Penelitian}

Waktu penelitian dilaksanakan pada bulan Oktober 2013.

\section{Subjek Penelitian}

Sumber data adalah subjek dimana data itu diperoleh (Arikunto, 2002). Adapun subjek penelitian ini adalah menggunakan metode sampling, peneliti hanya mewawancarai sebagian dari keseluruhan subjek. Subjek penelitian ini adalah Perpustakaan UIN Sunan Kalijaga Yogyakarta. Dalam memperoleh data, penulis menentukan orang-orang yang mengetahui hal-hal yang berkaitan dengan penelitian dan dijadikan sebagai informasi, sumber data diperoleh dari:

1. Koordinator layanan informasi Perpustakaan UIN Sunan Kalijaga Yogyakarta, bernama Isrowiyanti, S.Ag., SS

2. Relawan di Pusat Layanan Difabel UIN Sunan Kalijaga Yogyakarta berjumlah 2 mahasiswa. Peneliti mewawancarai dua relawan PLD, bernama Fairuz Khairina dan Muhtar Judin.

3. Staf part time Layanan Difabel Corner Perpustakaan UIN Sunan Kalijaga Yogyakarta, bernama Abdullah Fikri.

4. Mahasiswa Tunanetra yang masih aktif kuliah, berjumlah 2 mahasiswa. Peneliti mewawancarai: Rahman Agus Priyana dan Irmalia Nurjanah.

\section{Objek Penelitian}

Objek dalam penelitian ini adalah mahasiswa tunanetra di Perpustakaan UIN Sunan Kalijaga Yogyakarta, relawan Pusat Layanan Difabel UIN Sunan Kalijaga Yogyakarta, dan pustakawan yang menangani pelayanan difabel corner perpustakaan UIN Sunan Kalijaga Yogyakarta.

\section{Metode Pengumpulan Data}

\section{Metode Interview atau Wawancara}

Metode interview atau wawancara adalah suatu bentuk komunikasi verbal semacam percakapan yang bertujuan untuk memperoleh informasi (Nasution, 2006). Dalam penelitian ini penulis mengumpulkan data dengan mengajukan pertanyaan-pertanyaan kepada informan. Sebelumnya penulis telah mempersiapkan kerangka pertanyaan-pertanyaan atau pedoman wawancara. Jenis wawancara yang dilakukan adalah wawancara kualitatif, yaitu wawancara yang pewawancaranya menetapkan diri sebagai masalah dan pertanyaan-pertanyaan yang akan diajukan. 


\section{Metode Observasi}

Observasi adalah metode pengumpulan data yang dilakukan dengan cara mengamati secara langsung terhadap objek yang diteliti (Moleong, 1987). Observasi dilakukan untuk mendapatkan data berdasarkan tinjauan peneliti secara langsung, guna membandingkan antara data hasil interview dengan data kenyataan yang ada di lapangan. Dalam penelitian ini penulis menggunakan observasi non partisipan, maksudnya adalah peneliti tidak terlibat secara langsung.

\section{Metode Dokumentasi}

Metode dokumentasi ini adalah metode untuk mengumpulkan data dengan menghimpun dan menganalisis dokumen-dokumen. Dokumen bisa berbentuk tulisan, gambar, maupun karya dari seseorang (Sugiyono, 2009). Metode dokumentasi yang di peroleh peneliti diantaranya adalah: data mahasiswa tunanetra, data relawan Pusat Layanan Difabel, data pengurus pelayanan perpustakaan UIN Sunan Kalijaga, pustakawan yang menangani pemustaka berkebutuhan khusus, tunanetra, dan dokumen-dokumen lain yang relevan.

\section{Pembahasan}

\section{Pelayanan Perpustakaan UIN Sunan Kalijaga Yogyakarta}

Perpustakaan UIN Sunan Kalijaga tergerak untuk memberikan kontribusi dan atensi yang lebih serius terhadap hak-hak mahasiswa difabel untuk memperoleh akses informasi yang sama kepada mahasiswa difabel, seperti mahasiswa pada umumnya. Kehadiran mahasiswa difabel memerlukan adanya pelayanan dan fasilitas yang khusus untuk mendukung kegiatan belajar dan dalam perkuliahan mereka (Ariyanto, 2012). Perpustakaan UIN Sunan Kalijaga dalam upaya menuju World Class University Library mencanangkan kegiatan yang mendukung keberhasilan belajar di perpustakaan UIN Sunan Kalijaga antara lain berupa kegiatan:

1. Menyediakan ruang khusus perangkat teknologi yang diperlukan volunteer (relawan) dan mahasiswa difabel untuk mendigitalkan bahan ajar yang mendukung kelancaran belajar mahasiswa difabel.
2. Menyelengarakan workshop antara perpustakaan dan mahasiswa difabel tentang kesadaran hak memperoleh layanan dan fasilitas perpustakaan.

3. Melaksanakan Training Of Trainer (TOT) bagi para relawan yang membantu para mahasiswa baru difabel dalam pemanfaatan fasilitas dan layanan informasi pada programuser education

4. Merancang ruang khusus untuk mahasiswa difabel yang dikenal sebagai blind corner yang dilengkapi dengan studio produksi sumber-sumber belajar bagi mahasiswa difabel.

Adapun pelayanan di Perpustakaan UIN Sunan Kalijaga yaitu:

1. Pelayanan teknis merupakan pelayanan yang diberikan pihak perpustakaan tetapi tidak bersifat langsung berhadapan dengan pemustaka. Yang termasuk pelayanan teknis adalah pengadaan, pengolahan bahan perpustakaan, dan pemeliharan bahan perpustakaan.

2. Pelayanan umum adalah pelayanan yang tidak bersifat langsung berhadapan dengan pemustaka. Pelayanan umum Perpustakaan UIN-SUKA adalah:

a. Layanan Sirkulasi layanan yang di berikan perpustakaan yang berkaitan dengan peminjaman dan pengembalian bahan pustaka.

b. Pelayanan Referensi, berhubungan dengan pemberian informasi dan pemberian bimbingan belajar. (Bafadal, 1996)

c. Pelayanan Serial adalah berisi koleksi berseri: majalah, jurnal, koran, dan lainlain.

d. Pelayanan Multimedia, pelayanan berupa CD, DVD, kaset, untuk mahasiswa difabel dan non difabel. Mahasiswa tunanetra dapat memanfaatkan koleksi melalui digital library di komputer masingmasing dengan menggunakan aplikasi Job Access With Speech (JAWS).

e. Layanan Corner

- Canadian Resource Center (CRC): koleksi di CRC menyediakan koleksi informasi dalam bentuk buku-buku 
referensi terpilih, jurnal/buletin, $C D$ ROOm dan DVD serta software.

- Iranian Corner: koleksi khusus tentang Republik Islam Iran tentang tokoh-tokoh Syi'ah, revolusi Iran, kebudayaan Iran, jurnal dan lain-lain.

- Difabel Corner didirikan sebagai komitmen UPT Perpustakaan UIN Sunan Kalijaga untuk menjadi perpustakaan yang aksesibel baik secarafisikmaupunakademik. Difabel Corner ini diresmikan oleh Pembantu Rektor 1 UIN Sunan Kalijaga tanggal 20 Desember 2011. Difabel Corner merupakan layanan perpustakaan disediakan khusus untuk mahasiswa difabel, mahasiswa yang memiliki kebutuhan khusus. Difabel Corner menyediakan berbagai fasilitas akses sumber informasi: teknologi bantu, kepustakaan adaptif dan bantuan personal. Adapun koleksinya meliputi buku-buku Braille, audio book berbagai buku populer, E-book khusus yang ramah, koleksi skripsi digital, koleksi-kolesi buku kuliah, dan lain-lain. Dalam menggunakan komputer, mereka dibantu oleh aplikasi JAWS yakni aplikasi yang digunakan sebagai komputer bicara sehingga mahasiswa difabel tetap dapat membaca buku dalam bentuk elektronik maupun mengaplikasikan komputer.

\section{Keberhasilan Belajar}

\section{Proses Belajar}

Belajar adalah suatu proses usaha yang dilakukan individu untuk memperoleh suatu perubahan tingkah laku yang baru secara keseluruhan, sebagai hasil pengalaman individu itu sendiri dalam interaksinya dengan lingkungan (Moh. Surya, 1992, 23).

Belajar adalah proses perubahan perilaku berkat pengalaman dan latihan, tujuan adalah perubahan tingkah laku, baik menyangkut pengetahuan, keterampilan maupun sikap, bahkan meliputi segenap aspek organisme atau pribadi (Djamara, 2006).

\section{Pengertian Keberhasilan Belajar}

Indikator yang dijadikan sebagai tolak ukur dalam menyatakan bahwa suatu proses belajar mengajar dapat dikatakan berhasil adalah:

- Daya serap terhadap bahan pelajaran yang diajarkan mencapai prestasi tinggi, baik secara individu maupun kelompok.

- Perilaku yang digariskan dalam tujuan pengajaran/ instruksional khusus (TIK) telah dicapai siswa baik individu maupun klasikal (Usman, 1993).

\section{Keberhasilan Belajar Mahasiswa Tunanetra dari Peranan Pelayanan Perpustakaan UIN Sunan Kalijaga Yogyakarta}

\section{Berdasarkan Indikator Keberhasilan} Belajar:

1. Daya serap terhadap bahan pelajaran yang diajarkan mencapai prestasi tinggi, baik secara individu maupun kelompok.

Layanan perpustakaan bagi mahasiswa tunanetra Difabel Corner Perpustakaan UIN Sunan Kalijaga Yogyakarta sudah mendukung proses akademik sehingga keberhasilan belajar dalam perkuliahan dapat dicapai oleh mahasiswa tunanetra guna menunjang akademik. Pelayanan dan fasilitas di Perpustakaan UIN Sunan Kalijaga Yogyakarta dapat dikatakan baik.

Sebagaimana yang telah disampaikan oleh informan pertama, Rahman Agus Priyana, mahasiswa tunanetra Fakultas Tarbiyah dan Keguruan dalam kutipan wawancara berikut:

"pelayanan dan fasilitas yang diberikan untuk kami (mahasiswa tunanetra) sudah lumayan cukup baik, ada scanner, komputer, DVD dan lainnya mbak".

Dari ungkapan informan Rahman Agus Priyana tersebut dapat disimpulkan bahwa mahasiswa sudah puas pada pelayanan yang diberikan oleh perpustakaan. Mengenai fasilitas-fasilitas penunjang pelayanan yang diberikan dapat diketahui bahwa fasilitas sudah cukup baik, dalam artian dapat mendukung keberhasilan belajar mahasiswa tunanetra.

Selain ungkapan dari informan pertama Rahman, bahwa fasilitas yang ada di 
Perpustakaan UIN Sunan Kalijaga sudah dapat memuaskan bagi pemustaka. Hal ini sesuai yang diungkapkan oleh informan Abdullah Fikri selaku Ketua Koordinator Difabel Corner, yang juga merupakan mahasiswa tunanerta Pascasarjana UIN Sunan Kalijaga:

"Layanan di sini (perpustakaan UIN Sunan Kalijaga) sudah terbuka sekali bagi mahasiswa, fasilitas yang ada juga boleh digunakan dengan mudah. Kalau kita butuh bantuan petugas perpustakaan mereka juga siap membantu".

Dari petikan di atas dapat diambil kesimpulan bahwa peranan pelayanan perpustakaan sudah memberi pelayanan yang memuaskan kepada pemustaka khususnya mahasiswa tunanetra. Pustakawan juga mempunyai kesiapan dalam melayani pemustaka dengan baik dan memuaskan, ketika mahasiswa tunanetra membutuhkan bantuan dalam mengakses informasi.

Peranan pelayanan Perpustakaan UIN Sunan Kalijaga yang memuaskan bagi pemustaka mahasiswa tunanetra tidak lepas dari kerjasama dengan relawan Pusat Layanan Difabel, sebagaimana disampaikan oleh informan Irmalia Nurjanah:

"Kalau kami butuh buku biasa minta bantuan relawan untuk mencarikan buku yang kami (mahasiswa tunanetra) butuhkan untuk mengerjakan tugas. Kadang relawan juga siap membacakan materi mbak".

Dari ungkapan tersebut dapat diambil keputusan bahwa peranan layanan perpustakaan yang memuaskan merupakan hasil peran dan kerjasama dari relawan. Kegiatan relawan diantaranya: mencarikan buku yang dibutuhkan mahasiswa tunanetra dalam menyelesaikan tugas, membacakan materi dari buku yang ada, yang belum bisa dimengerti oleh mahasiswa tunanetra, men-scan buku cetak untuk disimpan dalam bentuk digital.

Peranan pelayanan perpustakaan yang baik akan mempengaruhi keberhasilan belajar pemustaka dalam prestasi akademik, sebab semua informasi yang mereka butuhkan terkait dengan tugas yang berhubungan dengan perkuliahan, ilmu-ilmu lain terdapat di perpustakaan. Informasi dan pengetahuan yang diakses di perpustakaan dapat mendukung keberhasilan belajar. Dalam hal ini keberhasilan belajar dapat dilihat dari nilai prestasi akademik atau Indeks Prestasi Komulatif (IPK). Sebagaimana yang di ungkapkan oleh informan Abdullah Fikri:

"Sepengetahuan saya, para mahasiswa yang sering datang ke perpustakaan nilai IPK-nya tidak ada yang kurang dari 3,00 mbak, daripada mahasiswa yang jarang ke perpustakaan".

Dari ungkapan tersebut dapat diambil kesimpulan bahwa layanan perpustakaan kepada mahasiswa tunanetra mampu mempengaruhi keberhasilan belajar dan prestasi akademik mereka. Difabel Corner Perpustakaan UIN Sunan Kalijaga Yogyakarta merupakan media akses dan sumber informasi bagi mahasiswa difabel tunanetra dapat memberikan pelayanan yang memuaskan.

2. Perilaku yang digariskan dalam tujuan pengajaran/ instruksional khusus (TIK) telah dicapai siswa baik individu maupun klasikal (Usman, 1993).

Peranan layanan perpustakaan yang baik dapat membangun kegemaran mahasiswa untuk berkunjung ke perpustakaan. Perubahan perilaku mahasiswa dalam menggunakan layanan perpustakaan dapat dilihat dari frekuensi jumlah kunjungan mahasiswa tunanetra ke perpustakaan.

Hal sebagaimana disampaikan oleh informan Rahman Agus Priyana, dalam kutipan wawancara berikut:

"ya boleh di bilang lumayan, saya sering menggunakan layanan perpustakaan. Kalau ada level 1-10 boleh di bilang saya ada di level 6 atau 7"

Dari ungkapan diatas dapat disimpulkan bahwa informan (mahasiswa tunanetra) sering mengunakan layanan perpustakaan. Dalam proses pengamatan yang dilakukan, peneliti sering menjumpai informan Rahman menggunakan layanan difabel corner. Selain 
dari data jumlah pengunjung di Difabel Corner Perpustakaan UIN Sunan Kalijaga, jumlah pengunjungnya relatif banyak.

Peranan perpustakaan sebagai sumber dan pusat informasi sekaligus sumber pengetahuan, tentu akan menjadi tempat yang paling utama untuk mendapatkan kebutuhan informasi. Kebiasaan pemustaka untuk berkunjung ke perpustakaan, akan menciptakan perilaku positif mereka akan memperolah informasi dan pengetahuan yang dibutuhkan untuk mendukung proses keberhasilan belajar. Perilaku dan tekad yang besar mahasiswa tunanetra dalam mencari informasi di perpustakaan berdampak positif, yakni mampu memaksakan diri untuk mencari pengetahuan tanpa kenal putus asa, semangat mencari ilmu yang tinggi, dan memprioritaskan ilmu. Hal ini diungkapkan oleh Abdullah Fikri selaku informan:

"Ya sudah, kalau buku tidak ada, mau diapain lagi? Saya akan nyari di tempat lain. Misalnya, di KemenHumHAM kalau misalnya di mana-mana gak ada ya ke toko buku"

Dari petikan informan diatas dapat diketahui, bahwa apabila mereka membutuhkan buku yang diinginkan tidak ditemukan, (dalam artian sedang dipinjam orang lain), mereka (mahasiswa tunanetra) tidak langsung menyerah. Namun, mereka berusaha mendapatkan buku atau sumber informasi yang dibutuhkan ke perpustakaan lain.

Sikap petugas perpustakaan dalam melayani mahasiswa difabel tunanetra dengan non difabel tidak ada perbedaan. Bahkan petugas perpustakaan memberikan perhatian dan kepedulian yang lebih kepada pemustaka yang mempunyai keterbatasan fisik. Berikut ini kutipan dari Isrowiyanti, S.Ag., SS:

"Bersikap empati ketika mereka datang, membimbing, dan menyambut (pemustaka difabel) dengan baik mbak, kita mempunyai kepedulian lebih secara umum kepada mereka".

Dari kutipan diatas jelas pihak perpustakaan bersikap empati yang lebih kepada mahasiswa yang mempunyai keterbatasan fisik kurang baik dari penyambutan, pengarahan informasi, bimbingan ketika mereka tidak didampingi oleh para relawan/ reading service agar mereka mendapatkan kepuasan dalam hal pemenuhan informasi.

\section{Analisis data}

Berdasarakan analisis data dalam penelitian ini, peneliti sudah menganggap bahwa layanan Difabel Corner Perpustakaan UIN Sunan Kalijaga telah memenuhi standar confirmbility, creadibility, serta transferbility. Peneliti sudah menguji hasil penelitian berupa peranan pelayanan perpustakaan terhadap keberhasilan belajar. Dalam uji keabsahan data peneliti diperoleh dari beberapa informan baik mahasiswa tunanetra dan relawan bahwa kebanyakan mahasiswa difabel yang menggunakan fasilitas difabel corner mereka mengerjakan tugas di perpustakaan, mencari informasi, dan untuk men-scan koleksi untuk di jadikan bahan belajar di rumah. Mereka yang sering ke perpustakaan rata-rata mendapat nilai IPK sebagian besar di atas 3. Tahap uji transferbility peneliti melakukan penyusunan secara rinci, jelas dan sistematis baik berasal dari sumber primer maupun dari sumber sekunder. Sehingga pada tahap ini diharapkan orang lain dapat memahami tujuan penelitian ini dengan baik dari penelitian peranan perpustakaan dalam keberhasilan belajar mahasiswa tunanetra UIN Sunan Kalijaga Yogyakarta.

\section{Simpulan}

Penelitian dengan judul "Peranan Pelayanan Perpustakaan dalam Membantu Keberhasilan Belajar Mahasiswa Tunanetra (Studi Kasus di Perpustakaan UIN Sunan Kalijaga Yogyakarta)" dapat disimpulkan:

Pelayanan perpustakaan dapat mempengaruhi prestasi akademik mereka karena semua informasi yang mereka butuhkan terkait dengan tugas yang berhubungan dengan perkuliahan dan informasi lain terdapat di perpustakaan. Mereka banyak mencari informasi sumber rujukan di perpustakaan sehingga mampu meningkatkan prestasi akademik mereka. Dengan senangnya mahasiswa 
tunanetra ke perpustakaan ternyata merka mampu menyelesaikan tugasnya dengan baik.

Peranan pelayanan perpustakaan dan perlakuan petugas perpustakaan yang memuaskan kepada pemustaka difabel dapat mempengaruhi kegemaran berkunjung ke perpustakaan. Kebiasaaan pemustaka yang sering berkunjung ke perpustakaan akan menciptakan perilaku positif dan mereka akan senantiasa mencari informasi tak kenal putus asa.

\section{Saran}

1. Pihak perpustakaan memperbanyak koleksi digital untuk memenuhi kebutuhan mendapatkan informasi bagi mahasiswa difabel.

2. Pihak perpustakaan hendaknya sering berkomunikasi dengan pemustaka difabel untuk mengetahui kebutuhan mereka.

3. Pihak Pusat Layanan Difabel sebaiknya mengatur jadwal relawan dalam membantu kegiatan pelayanan perpustakaan agar mahasiswa difabel dalam mencari informasi lebih terkontrol.

\section{Daftar Pustaka}

Arikunto, Suharsimi. 2002. Prosedur Penelitian Suatu Pendekatan Praktek. Yogyakarta: Rineka Cipta.

Ariyanto, M Solihin. 2012. Perpustakaan UIN Sunan Kalijaga Menuju Class University Library. Majalah SUKA News UIN Sunan Kalijaga. Yogyakarta : Suka News.

Djamara, Syaiful Bahri dan Aswan, Zain. 2006. Strategi Belajar Mengajar. Jakarta : Penerbit Rhineka Cipta.

Lasa. Hs. 2005. Manajemen Perpustakaan. Yogyakarta: Gama Media.

Lewv J. Moleong. 1987. Metodologi Penelitian Kualitatif. Bandung: PT Remaja Rosda Karya.

Nasution, S. 2006. Metode Research Penelitian IImiah. Jakarta : Bumi Aksara.

Sugiyono. 2009. Metode Penelitian Pendidikan Pendekatan Kuantitatif, Kualitatif, dan R\&D. Bandung : Alfabeta.

Sumaryanto. 2011. "Upaya Pusat Studi Layanan Difabel Dalam Membantu Keberhasilan
Belajar Mahasiswa Tunanetra UIN Sunan Kalijaga" (Skripsi). Jurusan Bimbingan dan Konseling Islam Fakultas Dakwah Universitas Islam Negeri Sunan Kalijaga Yogyakarta.

Sutono, Nim Toha. 2013. "Persepsi Mahasiswa Difabel Terhadap Kualitas Pelayanan Perpustakaan UIN Sunan Kalijaga Yogyakarta" (Skripsi). Jurusan Bimbingan dan Konseling Islam Fakultas Dakwah Universitas Islam Negeri Sunan Kalijaga Yogyakarta.

Usman, Moh Uzer dan Lilis, Setiawati. 1993. Upaya Optimalisasi Kegiatan Belajar Mengajar. Bandung : Penerbit PT Remaja Rosdakarta. 